PART 4

ASTRONOMER'S HANDBOOK 


\title{
ASTRONOMER'S HANDBOOK
}

The Astronomer's Handbook (IAU Transactions XIIC, edited by J.-C. Pecker and IAU Transactions XIIIB, edited by L. Perek) contains documents of permanent value. Only the parts changed after the XIVth General Assembly are supplemented here. The numbering of paragraphs is the same as in XIIC.

\section{PART 1 OF ASTRONOMER'S HANDBOOK \\ I. SHORT HISTORY OF THE INTERNATIONAL ASTRONOMICAL UNION}

D. Table 2 should be supplemented as follows:

$\begin{array}{lc}\text { XIVth General Assembly, 1970, Brighton, Sussex, England } & \\ \text { Members of the Union, after the General Assembly } & 2590 \\ \text { Participants (850 Members) } & 2255 \\ \text { Number of Commissions } & 39 \\ \text { Volumes of Transactions A } & 566 \text { pages } \\ & 378 \text { pages } \\ \text { Bighlights 1970 } & 805 \text { pages } \\ \text { President: B. Strömgren } & 1970-73 \\ \text { General Secretary: C. de Jager } & 1970-73 \\ \text { Assistant General Secretary: G. Contopoulos } & 1970-73 \\ \text { Vice-Presidents: B. J. Bok } & 1970-76 \\ \text { B. Lovell } & 1970-76 \\ \text { E. R. Mustel } & 1970-76\end{array}$

II. ADMINISTRATION AND FINANCES OF THE UNION

\section{A. ADMINISTRATION}

The address of the Secretariat is:

\author{
International Astronomical Union \\ Space Research Laboratory \\ The Astronomical Institute \\ 21, Beneluxlaan \\ UTRECHT \\ The Netherlands
}

The Secretariat is headed by the General Secretary, C. de Jager. The staff of the office consists of the Executive Secretary, A. Jappel, the Secretary of the office, Mrs J. Daňková, and a typist. 